\title{
Nishga Initiative and Missionary \\ Response: Robert Doolan at \\ Quinwoch, B.C.
}

E. PALMER PATTERSON II

In this historical study of the work of pioneer missionary Robert Doolan, Professor Patterson points out the initiative shown by the Nishga people of the northwest coast of British Columbia and how this interest helped build the church there.

$\Delta$ people to come to their country is likely to be accepted as a "Macedonian call" and the implied interest in such an invitation is seen as providential working, regardless the motivations of the unevangelized. Such is the case with the Nishga Indians of the Nass River in northwest British Columbia who began coming downriver after the Hudson's Bay Company moved in 1834 to Fort Simpson on the Tsimshian Peninsula from the mouth of the Nass.

The Nishgas thus came in contact with a young lay missionary of the Church Missionary Society, William Duncan. He came to Fort Simpson in 1857 and in 1860 he accepted an invitation to visit the Nishga villages.

Two chiefs acted as guides and hosts: Kadounaha and Kinsahdah. In the villages Duncan was greeted with friendliness and courtesy, which allayed his initial misgivings. Special ceremonies were conducted in his honor and speakers at several meetings used phrases, perhaps learned from him, which helped convince Duncan that the Nishga were eager to learn more about Christianity:

E. Palmer Patterson II is the Associate Professor of History at the University of Waterloo, Ontario, Canada. He earned his Ph.D. at the University of Washington, Seattle in history. 
Heaven is about to put away the heart (the way) of the ancient people, is it? . . Pity us, great Father in heaven, pity us. Give us thy good book to do us good and clear away our sins. This chief (pointing to me) has come to tell us about thee. It is good, great Father. We want to hear. Who ever came to tell our [ancestors] thy will? No, no. But this chief has pitied us and come. He has thy book. We will hear. We will receive thy word. We will obey (Church Missionary Society 1865:114-115).

Thus encouraged, Duncan urged the C.M.S. to provide additional missionaries to answer this call. Meanwhile contact was maintained by Nishga visits to the community of Metlakatla, newly created by Duncan with his converts and catechumens in 1862. The visitors were taught Bible verses and then further contacts were made each spring when the Tsimshian of Metlakatla traveled north to the mouth of the Nass to fish. Duncan regarded the Nishga as the people next to be evangelized.

\section{A New Mlssionary Recruit}

In 1864 the C.M.S. sent out a young Church of England deacon to go to the Nishga - Robert Doolan, a graduate of Cambridge who was linked to the evangelical influence there of Charles Simeon and the Jesus Lane Sunday school. Doolan spent his first few months at Metlakatla learning Tsimshian (of which Nishga is a dialect) and being introduced to the mission work. At 31 he was impressed by the elder Duncan's accomplishments and mastery of the language.

In November when the Nishga hunting season ended, they returned to their winter villages. Quinwock, chosen as Doolan's post, was one of their five villages of the Nishga and the home of Kinsahdah and Kadounaha. Robert Cunningham, a sometime trader and lay missionary, lived here with his Nishga wife, and introduced Doolan to the village. His wife taught him the language. Doolan's letters and journals show that this companionship was especially important his first winter.

\section{Doolan's Daily Routine}

Of the three years Robert Doolan spent on the northwest coast of British Columbia he spent 20 months in Quinwoch, fitting evangelizing into the annual subsistence cycle of the Nishga. Fall and winter were spent in their villages; in the spring most moved to the annual fishing areas. In the summer some people moved 
on to the traditional food-gathering areas. The Nishga's rich ceremonial life occurred back in their villages in the fall and winter months.

Arriving in Quinwoch in November 1864 Doolan found Cunningham repairing the building loaned by the chief which he was to live and teach in. He found the fall weather cold and damp. Later when the snow fell it came in through the cracks in the walls. The new missionary's round of activities included maintenance as well as evangelizing. For food he bought potatoes from Nishga gardeners. He gathered firewood, performed household chores and was expected to assist the Nishga by selling and transporting food. To help finance the mission he bought and sold pelts.

Doolan studied both the Nishga dialect and Tsimshian with the help of a young Tsimshian, Robert Dundas, who had come with him as an interpreter from Metlakatla. Doolan never spoke enough Nishga to preach, but on Saturday Doolan and Cunningham would coach Dundas who then delivered the Sunday sermons, though imperfectly in Doolan's opinion (1864:Dec. 26). Some objected to Dundas' preaching, preferring to hear the European missionary. Doolan's journal shows his frustration at not having a command of the language: some young men taught him words which were "indecent"; others laughed at his mistakes. By January he was progressing somewhat. School began for children and adults, but Doolan found it impossible to maintain a formal atmosphere in the schoolroom. Everyone moved about in the building which was difficult to keep comfortably heated. Doolan began to visit the sick, providing medicines, setting broken bones, pulling teeth, performing amputations and giving refuge and protection. These occasions he used to talk about Christianity and European values. He confronted the native healers for what he regarded as their charlatanry and records evoking comments from them expressing skepticism about their own activities.

Study, prayer and meditation to sustain his own spiritual life were often interrupted by his many visitors, and it was too difficult to find time to write the required letters, reports and journals. Henry Venn, secretary of the C.M.S., regarded these accounts as essential to the missionary's work since they formed the basis of information for decision making at the center in 
E. PALMER PATTERSON II

Nishga Initiative and Missionary Response

340

London. Also material edited from these accounts was published in C.M.S. magazines and used to encourage support for the society. ${ }^{1}$

\section{Doolan's Oplnion of the Nishga People and Culture}

Doolan condemned the indigenous customs of cremation and pole burial (the common northwest coast custom of placing the corpse in a coffin atop a pole in the village). Daily life in the village was characterized by heavy drinking with resulting violence and accidents. At night men carried pistols concealed under their blankets and there seemed to be much fear and anxiety.

Because Doolan perceived most Nishga social events as heathen ceremonies, he was generally opposed to them. Doolan tried to persuade his students to avoid potlatches, feasts and pole-raisings since he thought attendance at such events might be taken for approval of them. He was well-informed about what transpired at these events and was disappointed to discover that several of his students had sung hymns at a ceremony given by Kinzarda. To support his campaign, Doolan refused to give medicine to those who participated in native ceremonies.

The living conditions of his "parishioners" disturbed Doolan - and he disapproved of what he perceived as the pride and status consciousness of the people. However he offered protection to those who came into conflict with others in the competition for prestige and status. His first year's account is full of alternating encouragement and disappointment, as individuals did or did not conform to the behavior Doolan hoped to instill in them.

At the end of his first tour in April 1865 Doolan summarized his feelings: his language difficulties impaired his ability to communicate; he dreaded the prospect of working without the companionship of Cunningham; the cold weather lowered his work efficiency; and constant interruptions, visits to the sick and bringing food into the village for sale made concentration difficult. His experience made him admire Duncan's achievements all the more. Doolan concluded his report by proposing that the C.M.S. expand upriver with an additional missionary and he offered part of his salary to meet the costs of a new appointment. 


\section{The Nishga Response to Doolan and Chrlstlanity}

Doolan also recorded the reactions of the people to his mission and to the presence of Europeans in the area in the journal of his third and longest tour - from October 1865 to May 1866. Several elements of European culture had already become part of Quinwoch life. Doolan notes the use of European blankets, some European clothing, firearms and alcoholic drinks. He refers to prostitution of Nishga girls and women in Victoria. Most of these changes were associated. with the coming of the fur trade, as were the introduction of tuberculosis and venereal disease. The fur trade continued to be important and Doolan was perceived, at least in part, as trader and provisioner.

Doolan saw his mission as bringing substantial change to the everyday life, religion, values, physical and social culture of the Nishga at Quinwoch. For him, Christianity and European culture were virtually equated, thus to be a Christian a major transformation in the life of the people was required. This is rather disparate from Henry Venn's "native church" idea being developed at this time. Venn proposed a native church self-supporting, self-governing and self-extending. With the pastoral work handled by native clergy, missionaries would be free to go to unevangelized areas. This plan was not implemented; instead, missionaries became pastors and some, such as W. H. Collison at Kincolith, and J. B. McCullagh at Aiyansh, continued at their Nass posts for almost three decades. ${ }^{2}$

To see missionaries in their own terms is difficult from a 20 th century context. It is equally difficult to see them from the perspective of the Nishga. Nevertheless, useful information about Nishga attitudes toward the missionary is available. Duncan's journal said the Nishga would gladly welcome a resident missionary and Quinwoch, as the home of Kinsahdah and Kadounaha, was the best place to start. Doolan's arrival may have generated a more ambivalent reaction to someone who challenged so many of their customs. His involvement in trading and provisioning was a positive contribution to the economy, and the house-school building already prepared indicates he was wanted.

Shortly after arriving, Doolan began to attract some young men. Cowcaelth, who became Philip Latimer - his first adult convert - seems to have been drawn to Doolan immediately. 
Cowcaelth had heard Duncan preach at Fort Simpson and was influenced by the experience. Doolan also met opposition in the early weeks from Kinzarda, several times referred to in Doolan's early journal as a bad man and an enemy. This opposition centered around resistance to Doolan's efforts to effect changes in village life. Kinzarda tried to dissuade Cowcaelth from developing a close friendship with Doolan and was upset because Cowcaelth had told Doolan about Kinzarda's part in traditional ceremonies which Doolan opposed.

Cowcaelth was a skilled artisan and maker of the paraphernalia used in the ceremonial life - which included pageants of a socioreligious nature where costumes and masks were used. Cowcaelth began to apply his carpentry skills to the service of his new mentor, making desks for the schoolroom.

Kinzarda continued to put pressure on the young people who were attracted to Doolan. Then in November 1864 Kinzarda sought Doolan's protection when he feared a rival chief whose crest pole he had overtopped. Thus Kinzarda, who had seen the missionary as disrupter of the culture, took advantage of Doolan's presence to escape the consequences of competitions indigenous to the Nishga culture. Doolan thus became involved in two commonly cited roles of the missionary in relation to the indigenous life: disrupter and refuge. While the missionary contributed to the disruption, other forms of conflict were already present. Northwest coast Indian culture was highly competitive with status seeking which expressed itself in conflict and tension within the community. The fur trade accelerated changes which by the middle of the 19th century took the form of population movements and decline, increased rivalry among native groups, changes in artistic accomplishments and changes in the technology employed in traditional activity.

During Doolan's first winter the Nishga tried to incorporate him into their culture. Kadounaha made a friendly visit at Christmas though Doolan noted that he had been long neglected by Kadounaha. Two days later Kadounaha talked to Cunningham about becoming a Christian, saying he hoped to do so without losing his position as a chief. Other visitors during this tour included a young man from upriver who took refuge from his family with Doolan.

Doolan continued to use his healing powers to supplement those of the traditional healer, though Doolan saw himself as a 
competitor and the native practitioner as a charlatan. In addition, the villagers continued to perceive Doolan as a fur trader and he was blamed when pelt prices fell. Some believed Doolan and Duncan were forcing prices down for their own profit.

Other grievances began to be voiced. Some chiefs accused Doolan and Cunningham of bringing sickness to the village children. Other chiefs wished to visit Doolan, but objected to doing so when so many of the common people were in his house. Some refused to take employment with Doolan and Cunningham.

Cowcaelth and his wife continued faithful in church attendance and support of Doolan, shunning Kinzarda's feasts. Kinzarda, who seems to have taken the lead in cultural adaptations, invited some of Doolan's scholars to sing hymns (taught them by Doolan) at one of his ceremonial occasions. He had earlier in the month held a feast on Sunday, explaining later to Cunningham when confronted with this breach of the sabbatarian Sunday, that the people were clean and in their best clothes, so the time seemed appropriate.

In early April 1865 when the villagers began to move downriver to the eulachon fishing area, Doolan went for a month to Metlakatla. His first tour on the Nass had brought responses which ranged from those who conformed closely to Doolan's instructions to those who had only a superficial contact with him. Many were willing to learn from him and let him help them but such a stance did not necessarily suit Doolan's intentions who saw such behavior as obstructionist and perverse.

Such an interpretation may account for Doolan's portraying Kinzarda as being primarily interested in raising his status in the community. In fact Doolan indicates that the missionary's presence formed part of Kinzarda's status-raising efforts.

\section{Conclusions}

Doolan showed an acute consciousness of the status differences among the Nishga and continually indicates when a chief is referred to. He was very disappointed by what he thought was the failure of Kinzarda and Kadounaha to follow up their initial interest in his teaching. The chiefs were a double challenge - as individuals and as influential models in the community. 


\section{E. PALMER PATTERSON II \\ Nishga Initiative and Missionary Response}

Doolan saw native ceremonies and feasts as evil, sinful and (in the case of healing) fraudulent. He refused to attend them and refused to give medical aid to those who attended, urging his followers to shun them. This stance, public and private, made his attempts to win over chiefs more difficult, since they were key figures in the ceremonial life, traditions and values which Doolan attacked. Their rejection of the culture would have community-wide implications. Adaptation and integration of selectively borrowed elements became their response in an attempt to prevent disruption and destruction of the community.

The initiative shown by the Nishga during Doolan's first tour on the Nass continued through the rest of his mission. Not until the creation of the Christian colony at Kincolith in 1867 were the relationships between Nishga and missionary to be altered.

\section{Notes}

1. Doolan's church and school records include the up and down statistics of attendance, labeled as reflecting a "body count mentality" by Ronda and Axtell (1978:48).

2. See Shenk's discussion of Venn's missiology (1977:467-485). Also Stock says Venn's idea of the native church did not extend to colonies of European settlement (1899:84).

References Cited

Church Missionary Society

1865 Church Missionary Intelligencer London

Doolan, Robert R.A.

1864 Journal CMS records CMS/A105 microfilm, Anglican Church of Canada, National Archives, Toronto

Ronda, James P., and James Axtell

1978 Indian Missions, A Critical Bibliography Bloomington, IN: Indiana University Press

Shenk, Wilbert

1977 "Henry Venn's Instructions to Missionaries" Missiology Vol. 4, No. 4

Stock, Eugene

1899 The History of the Church Missionary Society Vol. 2. London: Church Missionary Society 